\title{
Biomass and Chemical Composition of Tobacco Plants Under High Density Growth *
}

\author{
by S. J. Sheen
}

Department of Plant Pathology, University of Kentucky, Lexington, Kentucky, U.S.A.

\section{INTRODUCTION}

Isolation of crystalline Fraction I protein and Fraction II protein from close-grown immature tobacco plants has been recently achieved on a pilot-plant scale (2). Since Fraction I protein of tobacco leaf has been shown to have a higher protein efficiency ratio than casein (7), interest has been focused on tobacco as a crop for the production of dietary protein. In addition, the fibrous residue from the protein extraction process may be utilized as safer smoking material or animal feed and other usages are possible that would be further beneficial to mankind.

Wildman (15) indicated that a high density plant population and multiple harvest of immature tobacco plants could yield 150 metric tons of biomass and $1,626 \mathrm{~kg}$ of soluble protein (Fraction I and Fraction II protein) per hectare per year. Experiments with high populations transplanted in the conventional way have been independently conducted in the Burley and flue-cured tobacco regions. Woodlief et al. (16) followed flue-cured cultural practices for a plant population of $85,000-$ $100,000 / \mathrm{ha}$, and with three successive mid-growth harvests obtained 74 metric tons of biomass and $415 \mathrm{~kg}$ of soluble protein per hectare. However, nitrogen fertilization was a limiting factor for the accumulation of biomass and protein, especially for the ratoon crops. With adequate nitrogen fertilizer in the Burley growing re-

\footnotetext{
* Presented at the 35th Tobaceo Chemiscs' Research Conference, Winston-Salem, N.C., in 1981 .

Received: 22nd April 1982 - accepted: 7th Seprember 1982.
}

gion, a population of 250,000 plants / ha yielded more than 100 metric tons of biomass and over $1,000 \mathrm{~kg}$ of soluble protein from a single harvest at flower-bud stage, and a trend was observed that biomass and protein yield are positively correlated with plant population (5). High density stands can only be achieved by directfield seeding. As plant number increases, one would expect a population threshold at which growth competition and loss of bottom leaves may become so great that further gain in biamass and soluble protein yield could be nullified or decreased.

Aside from soluble protein production, the utilization of tobacco fibrous residue from the leaf protein extraction process is of economic importance. Residues from fresh alfalfa after extraction of soluble protein were dehydrated and used as animal feed (11). The deproteinized alfalfa residue showed a comparable nutritional value with alfalfa hay since the level of insoluble protein in the residue appeared to be sufficient for maintenance requirements in these experiments. The quality of tobacco fibrous residue as animal feed should depend upon the composition of various nutrients and/or toxins and digestibility. The present study was therefore undertaken with two objectives: [a] to determine the biomass and soluble protein yield from tobacco plants directly seeded in the field with an extremely high density, and [b] to examine the chemical composition of the deproteinized tobacco fibrous residue with respect to utilization as animal feed. Because of genotypic variation in biomass and protein accumulation reported in previous experiments $(5,12,13)$ the present study employed diverse tobacco genotypes for comparison. 


\section{MATERIALS AND METHODS}

Ten tobacco (Nicotiana tabacum L.) cultivars representing flue-cured, dark fire-cured, Burley, Oriental, and Maryland types were sown by broadcast-seeding on the Agricultural Experiment Station Farm of the University of Kentucky in Lexington in early spring 1980. The preparation of seed beds and the care of young seedlings were by the conventional Burley practices. Experimental plots were $1.5 \times 1$ meter surrounded by $20 \mathrm{~cm}$ height wood frames. When the seedlings reached approximately $20 \mathrm{~cm}$ in height and the cloth cover was removed from the bed, plants were thinned to $110-120$ per plot. Ammonium nitrate in solution was applied at $112 \mathrm{~kg}$ of nitrogen per hectare. In the middle of June when plants reached $50 \mathrm{~cm}$ or taller, all plants within $0.36 \mathrm{~m}^{2}$ area were cut about $12 \mathrm{~cm}$ above the ground. Three samples were taken from each plot. A total of 30 samples were separately processed for determination of biomass and chernical composition.

For each sample, leaves and stalks were separately weighed and biomass and leaf/stalk ratio were calculated. After shredding leaves and stalks, a $500 \mathrm{~g}$ sample of shredded tissues was homogenized with $500 \mathrm{ml}$ of icecold $2 \%$ sodium metabisulfite solution. The homogenate was strained through three layers of cheese-cloth and one layer of Miracloth, and subsequently the slurry was rinsed with one volume of cold water. The combined filtrate was centrifuged at $20,000 \mathrm{~g}$ for $30 \mathrm{~min}$. The light yellow supernatant was heated to $90^{\circ} \mathrm{C}$ to coagulate soluble protein. The protein coagulant was collected in a tared crucible and oven-dried $\left(80^{\circ} \mathrm{C}\right)$ for dry weight determination. Similarly, the fibrous residue was oven-dried for quantitation.

Dry fibrous residue was analyzed for the concentration of protein, starch, lipids, lignin, cellulose, and ash. For protein quantitation, $0.5 \mathrm{~g}$ of fibrous residue was digested in $6 \mathrm{~N} \mathrm{HCl}$ solution and the content of amino acids in the digested fluid was treated with ninhydrin and colorimetrically determined at $570 \mathrm{~nm}$ by use of a Technicon AutoAnalyzer with known quantities of amino acids as standards (9). Starch was quantitated at $600 \mathrm{~nm}$ by the modified iodine stain method of Gaines and Meudt (8). Lipid quantitation was carried out by refluxing $1 \mathrm{~g}$ of fibrous residue with hexane overnight, and the extracted residue was oven-dried in a tared crucible to determine weight loss. Cellulose and lignin quantities on an ash-free basis were determined according to the methods described by Bacot (3). Ash content was the residual weight of the fibers in a tared crucible after being charred in a muffle furnace at $550^{\circ} \mathrm{C}$ for $4 \mathrm{~h}$. The quantity of all above chemical constituents was expressed in terms of $\mathrm{mg} / \mathrm{g}$ dry weight. The difference in quantity of the above chemical constituents from $100 \%$ is considered as the concentration of apparent hemicellulose.

Neutral detergent fiber (NDF) and acid detergent fiber (ADF) have been identified as indicators of digestibility of forage crops in animals. In order to evaluate tobacco fibrous residue as a potential animal feed, the deprotein- ized samples were analyzed for NDF and ADF content according to Van Soest's methods (14). For comparison, three samples of fresh alfalfa (before the flower-bud stage) were processed for deproteinized fibrous residue according to the protein extraction method of Kobler et al. (11), and the residue was analyzed for all the above chemical constituents.

Alkaloid contamination may be a concern in utilization of deproteinized tobacco residue as animal feed since nicotine is known to be highly toxic. To examine the alkaloid levels before and after the protein extraction process, a similar field experiment was conducted in Lexington, Kentucky, in spring 1981. Field cultural practices and sampling methods were identical to those of the 1980 experiment. The replicated samples of six cultivars were freeze-dried and analyzed for the concentration of total alkaloid, total protein, nitrate-nitrogen and soluble sugar. Quantitative methods for these leaf constituents have been detailed elsewhere $(3,13)$. The same chemical constituents in the deproteinized fibrous residue were analyzed after each washing with a volume (10 $\times$ of residue weight) of water. The extremely low level of nicotine in the water-washed residue was quantified by the following procedure. One gram of sample was mixed with $250 \mathrm{mg}$ of $\mathrm{Ba}(\mathrm{OH})_{2}$ in a screwcap tube and shaken vigorously with $5 \mathrm{ml}$ of saturated $\mathrm{Ba}(\mathrm{OH})_{2}$ solution and $20 \mathrm{ml}$ of diethyl ether for $1 / 2 \mathrm{~h}$. One ml of 7-methyl quinoline $(2 \mu \mathrm{g})$ was used as an internal standard. The epiphasic ether layer was pipetted out and the aqueous layer was washed once with diethyl ether, which was again pipetted out. The combined ether layers were reduced in volume by a stream of nitrogen gas. The concentrate was analyzed for nicotine by GLC. A series of nicotine standards ranging from $1.6 \mu \mathrm{g}$ to $3.2 \mathrm{ng} / \mathrm{ml}$ and 7-methyl quinoline $(2 \mu \mathrm{g} / \mathrm{ml})$ was similarly processed and analyzed for calibration. The GLC analysis employed a Varian Model 3700 unit equipped with an alkali flame ionization detector and a $6 \mathrm{ft}$. glass column (1/8 in. inside diameter) packed with $10 \%$ Carbowax $20 \mathrm{M}(20 \% \mathrm{KOH}$ on $80 / 100$ Chromosorb WAW, Supelco). The GLC conditions were: column temperature, $175^{\circ} \mathrm{C}$ (isothermal); injector temperature, $210^{\circ} \mathrm{C}$; detector temperature, $230^{\circ} \mathrm{C}$; carrier gas, $\mathrm{N}_{2}(18 \mathrm{ml} / \mathrm{min})$; air-flow rate, $240 \mathrm{ml} / \mathrm{min}$; and $\mathrm{H}_{2}$ flow rate, $40 \mathrm{ml} / \mathrm{min}$. At the range of $10^{-12}$ $\mathrm{A} / \mathrm{mV}$ and attenuation of $1,1 \mathrm{ppm}$ of nicotine can be easily detected.

\section{RESULTS}

A plant density of $110-120$ plants $/ 1.5 \mathrm{~m}^{2}$ is equivalent to approximately 766,000 plants / ha $(310,000$ plants $/$ acre). Such a high density can be only achieved by direct-field seeding. Growth competition among the plants within a plot was evident. The growth rate of different tobacco genotypes affected biomass yield and leaf/stalk ratio (Table 1). The Mammoth gene in Ky $16 \mathrm{M}$ is apparently associated with high biomass and low leaf/stalk 
Table 1. Blomass and leaf/stalk ratio of tobacco cultivars grown under high density in a 1980 field experiment.

\begin{tabular}{|c|c|c|c|c|c|}
\hline $\begin{array}{l}\text { Tobacco } \\
\text { cultivar }\end{array}$ & \multicolumn{3}{|c|}{ (kg fresh weight $/ 0.36 \mathrm{~m}^{2}$ ) } & $\begin{array}{l}\text { Leaf/stalk } \\
\text { ratio }\end{array}$ & $\begin{array}{l}\text { Fresh biomass } \\
\text { (metric ton/ha) }\end{array}$ \\
\hline NC95 & 1.59 & 1.14 & 0.45 & 2.54 & 44.3 \\
\hline NC2326 & 1.70 & 1.26 & 0.44 & 2.86 & 47.2 \\
\hline Coker 139 & 2.09 & 1.67 & 0.41 & 4.04 & 58.1 \\
\hline Ky171 & 2.36 & 1.72 & 0.65 & 2.65 & 65.6 \\
\hline Ky 151 & 2.20 & 1.48 & 0.73 & 2.03 & 61.2 \\
\hline Ky16M & 2.54 & 1.62 & 0.92 & 1.77 & 70.5 \\
\hline Burley 21 & 2.25 & 1.61 & 0.64 & 2.52 & 62.5 \\
\hline Ky14 & 2.17 & 1.61 & 0.55 & 2.94 & 60.1 \\
\hline Xanthi (necrosis) & 1.75 & 1.16 & 0.59 & 1.97 & 48.7 \\
\hline MD609 & 1.64 & 1.23 & 0.41 & 3.02 & 45.5 \\
\hline \multirow{2}{*}{$\begin{array}{l}\text { Least significant } \\
\text { difference }\end{array}$} & 0.27 & 0.20 & 0.10 & 0.34 & 7.5 \\
\hline & 0.37 & 0.27 & 0.14 & 0.46 & 10.3 \\
\hline
\end{tabular}

ratio because of rapid stalk growth. On the other hand, the low leaf/stalk ratios for Oriental tobacco Xanthi (necrosis) and dark fire-cured tobacco Ky151 are possibly attributable to small leaves, large stalks, or both. Among the three flue-cured cultivars, Coker 139 had the highest leaf/stalk ratio. This is attributable to larger leaf size and more leaves per plant in Coker 139 than in NC95 and NC2326. For Coker 139, leaf number and size contributed to an increase of more than $20 \%$ of biomass, and its biomass yield reached a level comparable to those of Burley (Burley 21 and Ky14) and dark fire-cured tobacco (Ky171 and Ky151). However, difference in biomass yield was not significant among the two dark fire-cured tobaccos and the two Burleys. The performance of Maryland tobacco, MD609, most nearly resembled the low-biomass cultivars of flue-cured tobacco.
There was little variation of soluble protein yield per $\mathrm{kg}$ biomass among the experimental cultivars excluding NC95 and NC2326 (Table 2). NC95 and NC2326 yielded less soluble protein than Coker 139, suggesting that there are varietal differences among flue-cured tobaccos. Varietal difference within other tobacco types cannot be evaluated because only a small number of cultivars were compared. Nevertheless, differences existed between flue-cured and other tobacco types. On the basis of biomass yield per hectare, the calculated yield of soluble protein per hectare ranged from $304 \mathrm{~kg} / \mathrm{ha}$ for NC2326 to $519 \mathrm{~kg} / \mathrm{ha}$ for Ky171. Three Burley cultivars did not differ from Ky171 for soluble protein yield. Ky151 and Coker 139 yielded an intermediate level followed by MD609 and Xanthi (necrosis) in a descending order.

Table 2. Yield of soluble protein and deproteinized flbrous residue from high density grown tobaccos in a 1980 field experiment.

\begin{tabular}{l|c|c|cc}
\hline \multirow{2}{*}{$\begin{array}{c}\text { Tobacco } \\
\text { cultivar }\end{array}$} & \multicolumn{2}{c|}{ Soluble protein } & \multicolumn{2}{c}{ Deproteinized fibrous residue } \\
\cline { 2 - 5 } & $\mathrm{g} / \mathrm{kg}$ wet biomass & $\mathrm{kg} / \mathrm{ha}$ & $\mathrm{g} / \mathrm{kg}$ wet biomass & $\mathrm{kg} / \mathrm{ha}$ \\
\hline NC95 & 5.62 & 249.0 & 38.27 & 1695.3 \\
NC2326 & 6.45 & 304.4 & 35.92 & 1695.4 \\
Coker 139 & 7.20 & 418.3 & 34.61 & 2010.8 \\
Ky171 & 7.91 & 518.9 & 35.16 & 2306.5 \\
Ky151 & 7.42 & 454.1 & 38.14 & 2334.2 \\
Ky16M & 7.25 & 511.1 & 31.93 & 2251.1 \\
Burley 21 & 8.12 & 507.5 & 31.38 & 1961.3 \\
Ky14 & 7.68 & 461.6 & 34.52 & 38.93 \\
Xanthi (necrosis) & 6.99 & 340.4 & 31.74 & 1895.9 \\
MD609 & 7.54 & 343.1 & 5.33 & 1444.2 \\
\hline Least significant $\{\mathrm{p}=0.05$ & 1.21 & 58.8 & 7.30 & 281.0 \\
difference & 1.66 & 80.5 & 384.9 \\
\hline
\end{tabular}




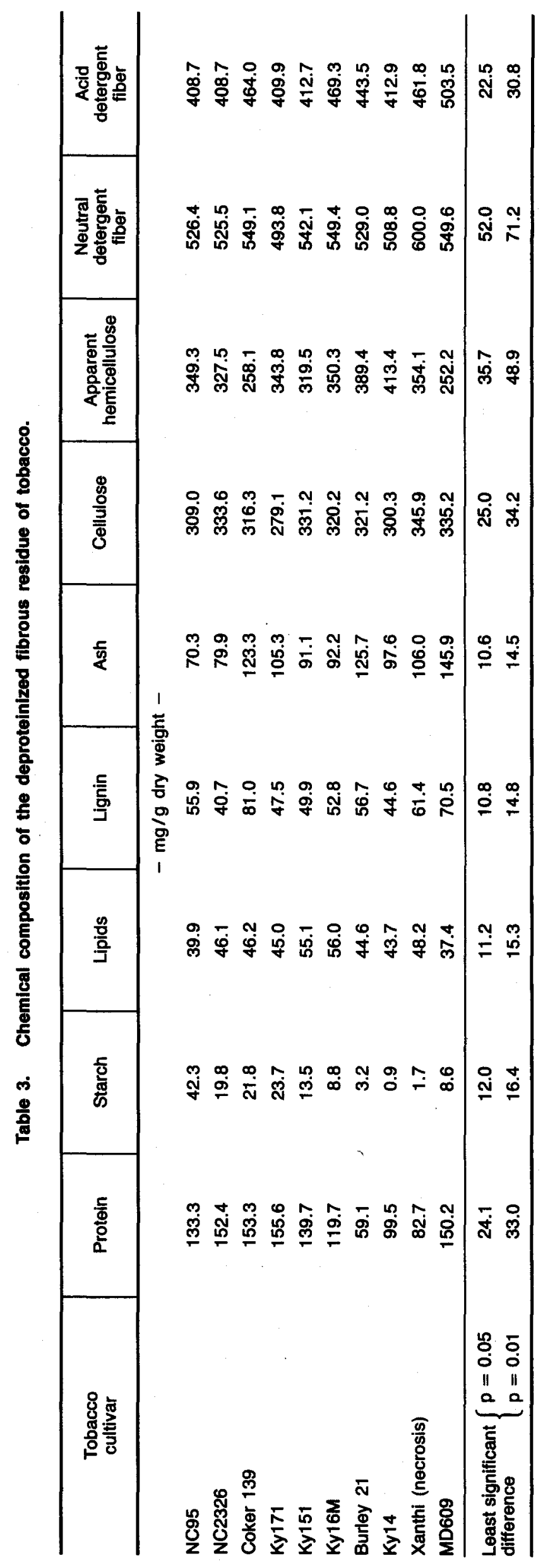


Table 4. A comparison of the chemical composition of the deproteinized flbrous residues of dark green and Burley tobaccos and alfalfa.

\begin{tabular}{l|c|r|r}
\hline \multicolumn{1}{c|}{$\begin{array}{c}\text { Chemical } \\
\text { composition }\end{array}$} & \multicolumn{1}{c|}{$\begin{array}{c}\text { Dark green } \\
\text { tobacco }\end{array}$} & Burley & Alfalfa \\
\hline \multicolumn{3}{c}{$-\mathrm{mg} / \mathrm{g}$ dry weight -} \\
Protein & $146.9 \pm 9.8$ & $92.8 \pm 30.9$ & $126.7 \pm 16.3$ \\
Starch & $24.2 \pm 10.8$ & $4.3 \pm 3.8$ & $5.8 \pm 1.3$ \\
Lipids & $46.5 \pm 5.5$ & $48.1 \pm 6.9$ & $62.5 \pm 0.8$ \\
Lignin & $55.0 \pm 15.5$ & $51.4 \pm 6.2$ & $95.6 \pm 7.2$ \\
Ash & $94.0 \pm 20.9$ & $105.2 \pm 18.0$ & $40.5 \pm 3.1$ \\
Cellulose & $313.8 \pm 22.0$ & $313.9 \pm 11.8$ & $427.0 \pm 17.9$ \\
Apparent hemicellulose & $319.6 \pm 36.4$ & $384.4 \pm 31.8$ & $241.8 \pm 16.3$ \\
Neutral detergent fiber & $527.4 \pm 21.3$ & $529.1 \pm 20.3$ & $618.4 \pm 37.4$ \\
Acid detergent fiber & $420.8 \pm 24.2$ & $441.9 \pm 28.2$ & $489.6 \pm 36.9$ \\
\hline
\end{tabular}

* Data for dark green tobacco are averages of NC95, NC2326, Coker 139, Ky171 and Ky151.

Ky16M, Burley 21 and $K y 14$ are used for calculating averaged values of Burtey.

Wildman (15) reported that the cellulosic residue of the protein extraction process from a close-grown tobacco population accounts for about $40 \%$ of dry biomass or $4 \%$ of wet biomass. The present results substantiate his estimation, with the quantities varying from 31.38 to $38.93 \mathrm{~g} / \mathrm{kg}$ wet biomass (Table 2). The water content of fresh tobacco plants under the present growth conditions was slightly greater than $90 \%$. Variations in water content and stalk volume among tobacco cultivars determined the percent weight of fibrous residue in wet biomass. Generally, Burley and MD609 yielded less fibrous residue per $\mathrm{kg}$ wet biomass than Oriental, fluecured, and dark fire-cured tobaccos. When computing fibrous residue yield on the basis of wet biomass production per hectare, the present cultural methods and one single harvest could produce about 2 metric tons of fibrous residue per hectare. Among the cultivars, Ky151 and Ky171 were the highest producers, followed by Ky16M, Ky14 and Coker 139. Poor producers were NC95, NC2326 and MD609, all of which yielded about $30 \%$ less than Ky151.

The chemical composition of fibrous residue from the ten tobacco cultivars is given in Table 3. The fibrous residue of all dark green tobaccos (flue-cured, dark firecured and Maryland types) contained $13 \%$ to $15 \%$ of dry weight as protein, whereas Burley and Oriental tobaccos varied within $6 \%$ to $12 \%$. Dark green tobaccos, excluding MD609, were also high in starch content, although varietal difference among flue-cured cultivars remained evident. Lipid content in the fibrous residue fell in the range of $4 \%$ to $5 \%$ and varied within and between tobacco types. Similarly, there were random variations in concentrations of lignin, cellulose, apparent hemicellulose, and ash among the cultivars analyzed. A one-fold difference ( $7 \%$ to $15 \%$ ) was obtained for ash content, and a similar magnitude of difference ( $4 \%$ to $8 \%$ ) existed for lignin concentration. The average cellulose content was $32 \%$ with a range of $28 \%$ to $35 \%$. The quantitative fluctuation of apparent hemicellulose was almost $40 \%$ with a varietal mean of $34 \%$. When pooling the quantities of lignin, cellulose and apparent hemicellulose together as the cellulosic components of fibrous residue, the average concentration reached $71 \%$ of dry weight. However, varietal difference did not exceed $15 \%$ with $767 \mathrm{mg} / \mathrm{g}$ dry weight in Burley 21 and $655 \mathrm{mg} / \mathrm{g}$ dry weight in Coker 139. Cellulosic components in terms of NDF and ADF showed a similar magnitude of variation (18\% and $19 \%$, respectively) among the cultivars. With the exception of Xanthi (necrosis) being significantly high in NDF content, the remaining cultivars had comparable amounts around $50 \%$ to $55 \%$ of dry weight. The quantity of ADF differed among tobacco types and within flue-cured and Burley tobaccos.

The average quantities of chemical composition in the deproteinized fibrous residues of dark green and Burley tobaccos and alfalfa are given in Table 4. As expected, the fibrous residue of dark green tobaccos contained more protein and starch than Burleys. The levels of the remaining fibrous constituents were very similar between the tobacco types except that Burleys seemed to have more apparent hemicellulose than dark green tobaccos. Alfalfa residue had high amounts of lignin, cellulose and lipids but low levels of ash and apparent hemicellulose. Protein content in alfalfa residue was intermediate between that of dark green and Burley tobaccos, whereas starch concentration resembled that of Burleys. Alfalfa residue contained about $15 \%$ more NDF and about $12 \%$ more ADF than tobacco. This probably reflects high concentrations of lignin and cellulose in alfalfa residue.

The 1981 field experiment provided the quantity of chemical composition in the dry biomass of six tobacco cultivars without deproteinization (Table 5). Under the high density growth, total protein quantity varied within the limit of $23 \%$ to $27 \%$ of dry weight, whereas soluble sugar ranged from $5.4 \%$ to $10.5 \%$. Nitrate-nitrogen accounted for $0.6 \%$ to $1.1 \%$ of dry weight. The concentration of alkaloids fell approximately within the same percentage range as nitrate-nitrogen with a varietal 
Table 5. Chemical composition of the Immature plants of tobacco cultivars grown under high density in a 1981 fleld experiment.

\begin{tabular}{|c|c|c|c|c|c|}
\hline & $\begin{array}{l}\text { obacco } \\
\text { Jitivars }\end{array}$ & Alkaloids & $\begin{array}{c}\text { Nitrate } \\
\text { nitrogen }\end{array}$ & $\begin{array}{l}\text { Soluble } \\
\text { sugar }\end{array}$ & $\begin{array}{c}\text { Total } \\
\text { prótein }\end{array}$ \\
\hline \multicolumn{6}{|c|}{ - $m g / g$ dry weight - } \\
\hline NC95 & & 6.5 & 6.3 & 105.0 & 232.5 \\
\hline Ky171 & & 7.2 & 6.7 & 82.0 & 236.9 \\
\hline Ky151 & & 9.8 & 7.0 & 53.7 & 251.3 \\
\hline Ky16M & & 9.4 & 7.5 & 62.7 & 248.1 \\
\hline Burley 21 & & 7.9 & 7.3 & 60.3 & 251.3 \\
\hline Ky14 & & 6.1 & 10.9 & 85.0 & 269.4 \\
\hline \multirow{2}{*}{$\begin{array}{l}\text { Least significant } \\
\text { difference }\end{array}$} & $p=0.05$ & 2.4 & 1.6 & 11.7 & 18.6 \\
\hline & $p=0.01$ & 3.4 & 2.3 & 16.6 & 26.4 \\
\hline
\end{tabular}

mean of $0.8 \%$. Since the extraction of soluble protein removed water-soluble substances including nicotine, the deproteinized fibrous residue generally contained less than $0.1 \%$ of dry weight as nicotine (data are not given). For example when the residue from Ky14 was sequentially washed with water $(1: 10(\mathrm{w} / \mathrm{v}))$, nicotine level in the residue was lowered to less than $1 \mathrm{ppm}$ after six washes. This thoroughly washed residue retained protein concentration at about $20 \%$ of dry weight. However, the soluble sugar content was lowered to less than $0.2 \%$ and the nitrate-nitrogen level became negligible.

\section{DISCUSSION}

Wildman (15) estimated a yield of 150 metric tons of fresh tobacco biomass per hectare from a stand of 370,000 plants and multiple harvests at a height of $45 \mathrm{~cm}$ to $50 \mathrm{~cm}$ in the region where the growing season is six to eight months. The present study with doubled plant population and a single harvest yielded an average of 56.7 metric tons of wet biomass per hectare. If ratooned shoots are harvested two more times, as is possible in Kentucky, the total biomass output per hectare would be close to that of Wildman's estimation.

In a previous experiment (5), a several-fold difference in biomass among $\mathrm{Ky} 16 \mathrm{M}, \mathrm{Ky} 14$, and $\mathrm{Ky} 171$ was obtained from the high density plots of 250,000 plants / ha. Although the population density was three times greater in the present experiment, the same cultivars differed in biomass yield by less than $18 \%$. Burley cultivars usually exhibit slow growth after transplant. Direct-field seeding would preserve their root system and enable plants to have continuous rapid growth. Rapid growth of certain tobacco genotypes under a high population density could result in reduced leaf size and elongated stalk. Ky16M showed the fastest growth and thus had the lowest leaf/stalk ratio. It became apparent that under direct-field seeding and high population density the agronomic characters vary greatly between and within tobacco types.
With the average of ten cultivars under investigation, one harvest could produce $413 \mathrm{~kg}$ soluble protein/ha, which was $0.73 \%$ of fresh biomass. The range among the cultivars was $0.56 \%$ to $0.81 \%$ for NC95 and Ky14, respectively. Wildman (15) estimated the percentage at $1.1 \%$, suggesting that an extreme of population density could lower the soluble protein yield. Naturally, reduced leaf size under high density growth would limit soluble protein accumulation. More importantly, a dense canopy causes early yellowing of bottom leaves and consequently lowers the accumulation of soluble protein in the leaf. Further experiments are needed to determine the appropriate population density, tobacco genotype, and their interaction for maximization of biomass and protein production. A comparison between direct-field seeding and transplanting should also be made. New technology in manufacture of seed pellets and seed tapes for direct-field seeding of tobacco has produced encouraging results recently in northern Florida (1).

Desirable characteristics of forage hay in relation to ruminant nutrition are high protein quantity and quality, low cellulose, lipid and lignin content, and high digestibility. Soluble protein has been extracted from fresh alfalfa and the resultant deproteinized residue showed nutritional value as good as that of alfalfa hay prepared conventionally (11). In comparison to the deproteinized alfalfa residue (Table 4), the deproteinized tobacco residue contained more protein and apparent hemicellulose but fewer lipids and less cellulose, and lignin. The chemical composition, therefore, suggests that the green tobacco fibrous residue from the leaf protein extraction process may be superior to the deproteinized alfalfa residue as animal feed. Van Soest and Wine (14) reported that the difference between NDF and ADF content in forage crops estimates hemicellulose. In the present study, the apparent hemicellulose content of alfalfa was about twice the difference of NDF and ADF quantities, whereas it reached 3 to 4.4 times greater for dark green and Burley tobaccos, respectively. Bailey and Ulyatt (4) quantitated the carbohydrate and lignin composition of detergent-extracted residues from pasture grasses and legumes and concluded that direct measurement of legume tissue with acid detergent produced variable results 
and thus may not be used for estimation of hemicellulose. This also seems to be true for tobacco fibrous residue. The results of the investigations into cellulosic composition indicate that the chemical components and structure of the tobacco cell wall may differ considerably from those of grasses and legumes.

In addition to fibrous residue, the soluble tobacco protein extraction process yields green insoluble precipitate as a by-product. This precipitate is composed of chloroplasts, starch granules, and cell debris and thus is high in protein, carbohydrates, and fipids, including carotenoids. According to Wildman (15), 150 metric tons of biomass / ha could produce $2,218 \mathrm{~kg}$ of green insoluble precipitate which would serve as an ideal feed for monogastric animals such as poultry and swine.

Aqueous tobacco leaf filtrates or tobacco stalks and stalk juice reportedly induced congential arthrogryposis in the new-born pigs of sows fed the diet, although there were no signs of toxicosis on feeding animals (6). The specific agent in tobacco responsible for this malformation is unknown. Crowe (6) conducted a series of experiments feeding animals with nicotine (up to $0.3 \mathrm{~g}$ per sow), insecticide, and maleic hydrazide and found no evidence of toxicity and no deformed pigs were born. Keeler (10) observed similar bone deformities in calves fed Nicotiana glauca and speculated that anabasine, a minor alkaloid in $N$. tabacum but a predominant one in $N$. glauca, might be the teratogen. Anabasine constitutes less than $1 \%$ of total alkaloids in N. tabacum and immature tobacco plants contain about $0.5 \%$ to $0.8 \%$ of dry weight as alkaloids. Deproteinized fibrous residue would have approximately one-tenth of this quantity because alkaloids are removed along with leaf juice. Water-soluble substances can be further lowered to a negligible level by washing. If nicotine level is decreased to $1 \mathrm{ppm}$, the level of anabasine should be below $10 \mathrm{ppb}$. From the data presented, it appears that the deproteinized fibrous residue of tobacco may be utilized as supplemental animal feed. Animal response studies with the deproteinized fibrous residue of tobacco will be conducted in the near future.

\section{SUMMARY}

Ten tobacco cultivars representing various tobacco types were directly seeded in the field at 70 to 80 plants per square meter and were harvested when 50 to $60 \mathrm{~cm}$ high. Biomass yield ranged from 44 to 70 metric tons per hectare, with Ky16 Mammoth having the highest yield. The Mammoth variety, however, had the lowest leaf/stalk ratio (1.77), whereas Coker 139 had the highest (4.04). One metric ton of wet biomass produced about 6 to $8 \mathrm{~kg}$ of soluble protein, which is independent of the leaf/stalk ratio. Analyses of the deproteinized fibrous residues revealed that the levels of neutral detergent fiber, acid detergent fiber, cellulose, and apparent hemicellulose were comparable among the ten cultivars. A large variation of lignin content was observed among the dark green tobaccos. Burley, in genteral, had lower concentrations of starch and protein in the fibrous residue than the dark green tobacco. When compared with the deproteinized alfalfa fibrous residue, the low concentrations of lipids, lignin, and celiulose and a greater amount of apparent hemicellulose in the tobacco residue show its suitability as animal feed. The present results also indicate that the selection of tobacco genotypes is of importance for high density cultivation in the production of soluble protein and fibrous residue.

\section{ZUSAMMENFASSUNG}

Zehn Tabak-Cultivare unterschiedlichen Typs wurden direkt auf dem Feld mit 70-80 Pflanzen je $\mathrm{m}^{2}$ ausgesät und bei einer Höhe von $50-60 \mathrm{~cm}$ geerntet. Der Massenertrag lag zwischen 44 und 70 Tonnen je Hektar, wobei Ky16 Mammoth den höchsten Ertrag hatte. Jedoch zeigte die Mammoth-Varietät das niedrigste Blatt/ Strunk-Verhältnis $(1,77)$, während Coker 139 mit 4,04 den höchsten Wert erreichte. Eine Tonne feuchter Biomasse erbrachte unabhängig vom Blatt/Strunk-Verhältnis 6 bis $8 \mathrm{~kg}$ löslichen Proteins. Analysen der entproteinierten Faserrückstände zeigten, daß die Mengen von Cellulose und Hemicellulose und von in neutralen bzw. sauren Detergentien löslichem Fasermaterial bei den zehn Cultivaren ähnlich waren. Bei den dunkelgrünen Tabaken wurden große Variationen des Ligningehaltes festgestellt. Burley zeigte grundsätzlich niedrigere Konzentrationen von Stärke und Protein im Faserrückstand als die dunkelgrünen Tabake. Verglichen mit entproteinierten Faserrückständen der Luzerne bestätigten die niedrigen Konzentrationen an Lipiden, Lignin und Cellulose und der höhere Anteil an Hemicetlulose in Tabakfaserrückständen, daß diese als Viehfutter geeignet sind. Die vorliegenden Ergebnisse zeigen auch, daß die Selektion von Tabak-Genotypen für die Kultur bei hoher Pflanzendichte bei der Gewinnung von löslichem Protein und Faserrückstand von Wichtigkeit ist.

\section{RESUME}

Dix variétés de tabac ont été semées directement dans un champ, à raison de 70 à 80 plantes au mètre carré, qui furent récoltées lorsqu'elles eurent atteint une hauteur de 50 à $60 \mathrm{~cm}$. Le produit de la biomasse se situait entre 44 et 70 tonnes à I'hectare, le Kyl6 Mammoth donnant le plus haut rendement. Toutefois cette dernière variété réalisa le plus petit rapport feuille/tige $(1,77)$, le rapport le plus important étant atteint par la variété Coker 139, soit 4,04 . Indépendamment du rapport feuille/tige, une tonne de biomasse humide fournit de 6 à $8 \mathrm{~kg}$ de protéines solubles. Des analyses des résidus de fibres déprotéinés ont montré que les quantités de cellulose, d'hémicellulose et de fibres solubles dans les détergents neutres ou acides étaient analogues pour les dix variétés. On a 
constaté d'importantes variations de la teneur en lignine pour les tabacs verts sombres. Le Burley présente des concentrations généralement plus faibles en amidon et protéine dans ses résidus fibreux, que les tabacs verts sombres. Comparés aux résidus déprotéinés de la luzerne, les faibles concentrations en lipides, lignine et cellulose, ainsi que la plus grande proportion d'hëmicellulose contenue dans les résidus de tabac, confirment le fait que ceux-ci peuvent être utilisés comme aliment du bétail. Ces résultats montrent également l'importance d'une sélection de gênotypes du tabac en vue d'une culture en grande densité pour la producțion de protéine soluble et de résidus fibreux.

\section{REFERENCES}

1. Akehurst, B. C.: Tobacco (second edition); Longman Inc., New York, 1981, pp. 764.

2. Anonymous: The golden leaf, Valuable new source of protein; North Carolina Farm Bureau News, December 1981, pp. 10-11.

3. Bacot, A. M.: The chemical composition of representative grades of the 1952 and 1954 crops of fluecured tobacco; U.S. Department of Agriculture Technical Bulletin No. 1225, 1960, pp. 126.

4. Bailey, B. W., and M. J. Ulyatt: Carbohydrate and lignin composition of detergent-extracted residue from pasture grasses and legumes; N. Z. J. Agric. Res. 13 (1970) 591-604.

5. Bernstein, A. B., R. H. Lowe and S. J. Sheen: Biomass and protein yield of tobaccos grown at three plant densities; Tobacco Research 8 (1982) $1 \rightarrow 12$.

6. Crowe, M. W.: Tobacco - A cause of congenital arthrogryposis; in: Effects of poisonous plants on livestock, edited by R. F. Keller, K. R. Van Kampen and L. F. James, Academic Press, Inc., New York, 1978, pp. 419-427.

7. Ershoff, B. H., S. G. Wildman and P. Kwanyuen: Biological evaluation of crystalline Fraction I protein from tobacco; Proc. Soc. Exp. Biol. Med. 157 (1978) 626-630.

8. Gaines, T. P., and W. J. Meudt: Adaptation of the iodine stain method for determining starch in fluecured tobacco; Tobacco Science 12 (1968) 130-133.

9. Hamilton, J. L., and R. H. Lowe: Changes in the concentrations of proteins, amino acids and ammonia in Burley tobacco during air-curing; Tobacco Science 22 (1978) 89-93.
10. Keeler, R. F.: Congenital defects in calves from maternal ingestion of Nicotiana glauca of high anabasine content; Clin. Toxicol. 15 (1979) 417-426.

11. Kohler, G. O., S. G. Wildman, N. A. Jorgensen, R. V. Enochian and W. J. Bray: Leaf protein in relation to forage crop production and utilization; in: Protein resources and technology, edited by $M$. Milner, N. S. Scrimshaw and D. I. C. Wang, AVI Publishing Company, Inc., Westport, Connecticut, 1978, Pp. 543-568.

12. Lowe, R. H., and S. J. Sheen: Accumulation of soluble proteins and nitrogenous compounds in the leaf of bright and Burley tobaccos during the growing season; Beitr. Tabakforsch. Int. 11 (1982) 161-169.

13. Sheen, S. J., R. H. Lowe and H. R. Burton: Leaf proteins and chemical constituents in tobacco chlorophyll genotypes; Beitr. Tabakforsch. Int. 11 (1982) 170-179.

14. Van Soest, P. J., and R. H. Wine: Use of detergents in the analysis of fibrous feeds, IV. Determinations of plant cell wall constituents; J. Assoc. Off. Anal. Chem. 50 (1967) 50-55.

15. Wildman, S. G.: Tobacco, a potential food crop; Crops and Soil Magazine, January 1979, pp. 7-9.

16. Woodlief, W. G., J. F. Chaplin, C. R. Campbell and D. W. DeJong: Effect of variety and harvest treatments on protein yield of close-grown tobaccco; Tobacco Science 25 (1981) 40-43.

\section{Acknowledgements}

This research was supported in part by the U.S. Department of Agriculture (Cooperative Agreement No. 12-14-7001-1041). The author is grateful to the Analytical Laboratory, Department of Agronomy, University of Kentucky, for nitrate-nitrogen and soluble sugar analyses. This paper is published with the approval of the Director of the Kentucky Agricultural Experiment Station as Joumal Series paper No. (82-11-62).

Author's address:

Department of Plant Pathology,

College of Agriculture,

University of Kentucky,

S-305 Ag. Science Bldg.-North,

Lexington, Kentucky, 40546, U.S.A. 